\title{
RACE/CASTE AND THE CREATION AND MEANING OF IDENTITY IN COLONIAL SPANISH AMERICA
}

\author{
POR \\ ROBERT H. JACKSON \\ Universidad de Texas
}

Tras un análisis de la historiografía reciente, se estudia el problema de la definición de raza y casta en la frontera de Sonora y Cochabamba. Se mantiene que la identidad racial ha sido históricamente mucho más subjetiva de lo que se ha supuesto. Consecuentemente, la categorización del sistema español de castas estaba más ligada a percepciones españolas abstractas que a realidades culturales $y$ sociales.

Two seminal studies published in the 1960 s presented differing interpretations of the nature of race in the Americas. Race Mixture in the History of Latin America written by Magnus Mörner focused on the rise and decline in colonial Latin America of the "sociedad de castas", a race based discriminatory social and legal system that defined the status of an individual based upon categories created and defined by the dominant predominately white colonial elite, priests, and bureaucrats. Mörner relied heavily on the analysis of the race/caste terms that appear in Spanish documents to define the process of mestizaje (racial mixture) and the legal and social status of castas (individuals defined as being of mixed racial ancestry), although the author does recognize that regional variations occurred in the use of race/caste terms. Mörner also argued that by the end of the colonial period in Spanish America the caste system had already begun to "crum-

SIGLAS UTILIZADAS:

AF: Archivo Franciscano. Biblioteca Nacional, México DF.

AGEMS: Archivo del Gobierno Eclesiástico de la Mitra de Sonora, Hermosillo.

ANB: Archivo Nacional de Bolivia, La Paz.

BLB: Brancoft Library, Berkeley. 
that regional variations occurred in the use of race/caste terms. Mörner also argued that by the end of the colonial period in Spanish America the caste system had already begun to "crumblew (1). Mörner also published two lists from Mexico and Peru of the meaning of different race/caste categories, although a number of the terms were never used in censuses or parish registers (See Appendix 1).

Anthropologist Marvin Harris attempted to discover the origins of racism in the Americas in a book entitled Patterns of Race in the Americas. Harris looked to economic relations as a key determinant in the rise of racism, but also documented an important study of perceptions of race in modern Brazil. The study showed that a number of factors determined the perceptions of race and status, including the economic and socio-racial status of the observer as well as the type of clothes worn by the individual being assigned a socio-racial identity (2).

Since the 1960s a number of scholars have used the dynamic of race and caste as a paradigm for understanding the evolution of Latin American society, especially during the colonial period. Following Mörner's lead, some specialists in Latin American social history have employed the censuses and parish registers that recorded and assigned race/caste identity, often without seriously questioning the subjectivity and imprecision of these sources as indicators of the realities of race based social status. Researchers frequently view Latin American society through the colored lens of the Spanish caste system without considering if the caste system accurately reflects social realities. Moreover, there is a tendency to view rigid differences between individuals identified by different race/caste categories in censuses and parish registers as being valid.

In a 1978 study anthropologist John Chance examined the urban society of Antequera (modern Oaxaca) in southern Mexico making extensive use of censuses and parish registers. Chance argued that the race/caste terms used in these records reflected social status (calidad) rather than strict biology. However, citing a statement made by the archbishop of Mexico in 1815, Chance maintained that the categorization of an individual using a specific race/caste term was not the result of the "whim of the priests». Rather, according to the author, "classifications were

(1) Magnus MöRnER, Race Mixture in the History of Latin America, Boston, 1967.

(2) Marvin Harris, Patterns of Race in the Americas. New York, 1964. 
based on the declarations of the parties concerned" (3). Chance did not test an assumption that underlies many recent studies of race and identity in Spanish America that employ documents that record race/caste identity.

Other scholars have accepted the race/caste terms recorded in censuses at face value without questioning their meaning or value as indicatdrs of social status. In a 1990 article entitled "Population and Ethnicity in Early Republican Peru: Some Revisions", for example, Paul Gootenberg employed a set of censuses to describe Peruvian society, the degree of ethnic/ racial mixing, and the decline in the Indian population in the 1820s. Gootenberg gave lip service to social factors and power relations which may have modified the evolution of the indio category which the author recognized as being «essentially [a] social, even political definition" and extremely fluid. Gootenberg then contradicts himself by suggesting that meaningful differences existed between indigenous peasants and other peasants not categorized as indios: "The murky evidence suggests overall the consolidation of more "pseudo-Indian" villages ... where all sorts of peasants mimicked many of the norms of cooperative labor and resources of indigenous folk, whether out of necessity or advantage" (4). Gootenberg appears to accept the underlying stereotypical assumptions of the Spanish caste system that attributes specific behaviors and characteristics to individuals or groups placed by priests or census takers into one or another race/caste category. By the logic of this assumption "mestizo" peasants must have behaved in a significantly different fashion than "Indian" peasants since they were placed in different categories by priests or colonial officials, and therefore mimicked as Gootenberg believes the behavior of "Indian" peasants.

As suggested in a recent article that echoes Marvin Harris's findings on the subjectivity of race in the Americas, the unquestioning use of censuses and parish registers to describe Spanish American society and the process of mestizaje need to be reconsidered (5). The Spanish race/caste system and social policy in Latin America has much in common with social policy in other 130.

(3) John Chance, Race and Class In Colonial Oaxaca Stanford, 1978, pp. 128-

(4) Paul Gootenberg, «Population and Ethnicity In Early Republican Peru: Some Revisions", Latin American Research Review. Vol. 26, no. 3, 1991, pp. 109. 157.

(5) Robert H. JACKSON and Gregory MADDOX, "The Creation of Identity: Colonial Society in Bolivia and Tanzanian, Comparative Studies in Society and History. Vol. 35, no. 2, 1993, pp. 263-284. 
colonial situations, such as nineteenth and twentieth century British India and Africa. Colonial administrators frequently attempted to enhance their control over subject peoples by playing a game of divide and rule which was facilitated by placing them into categories and playing those categories off against each other. In India, for example, the British played Muslims off against Hindus, and placed existing castes into a hierarchy that determined the legal and social status of caste members in colonial society. The British used censuses to rank and characterize castes. In other situations the British created polities such as tribes from scratch in order to implement systems of indirect rule, a system of local governance by indigenous leaders given the authority to govern by British officials. Colonial peoples also manipulated the system by changing their behavior to conform to the stereotypical ideas of the colonizers of how people placed into certain categories should behave. Historian Robert McCaa referred to shifts in racial status (calidad) as "racial drift" (6).

Moreover, as McCaa suggests, the definition of race in Spanish America is extremely complex:

Calidad, typically expressed in racial terms (e.g. indio, mestizo, español), in many instances was an inclusive impression reflecting one's reputation as a whole. Color, occupation, and wealth might influence one's calidad, as did purity of blood, honor, integrity, and even place of origin. Clase, on the other hand, in its classical sense referred to occupational standing but included dimensions of wealth and race (7).

The sources themselves contain fundamental flaws which modify or even invalidate conclusions based on them. Definitions of categories changed over time, often as a consequence of changing policy or socio-economic change. For example, the «indio" population of one region in Bolivia dropped in the nineteenth century as a result of the erosion of the colonial-era tribute system. In the case of parish registers, especially baptismal registers, the race/caste category assigned to an individual, usually a newborn, was also subject to the whim of the presiding priest. Finally, the placement of people into subjective and stereotypical race/caste categories did not take into consideration cultural

(6) Robert McCAA, "Calidad, Class, and Marriage in Colonial Mexico: The Case of Parral, 1788-1790", Hispanic American Historical Review. Vol. 64, no. 3, 1984, pp. 477-501.

(7) Ibid., 477-478. 
changes that transcended race/caste categories. In other words, citing the case of Gootenberg's article discussed above, Peruvian peasants probably shared a common culture, social structure, and economic organization which did not conform to the stereotypical elite perceptions of how peasants classified as «indio" or "mestizo" should act (8). Finally, an examination of race/caste in Spanish America from the perspective of the creation of identity in a colonial situation helps reconcile the contradictions apparent in the approaches of Mörner and Harris.

This essay examines two case studies that illustrate different aspects of the creation and modification of race/caste identity in two distinct societies in colonial Spanish America. The first was a rapidly changing frontier in northern Mexico (Sonora) where a highly mobile settler population generally included in the mixedblood category displaced a declining indigenous population congregated in mission communities. An analysis of censuses and parish registers shows that priests used different race/caste terms to categorize the population. The second is the Cochabamba region of Bolivia, a highly developed grain producing region dominated by corporate indigenous communities created by crown action in the late sixteenth century, and haciendas with a servile labor force recruited from the local communities as well as migrants to Cochabamba from the altiplano (high altitude plains) trying to escape the excessive tribute and labor demands of the colonial state. The study of the Valle Alto, a small valley in Cochabamba almost exclusively controlled by haciendas, links the decline of the number of peasants categorized as «indios" (a strictly legal and fiscal category) to the decline of the tribute system in the nineteenth century and changes in other government policies. Finally, both case studies share one element in common, the impact of early nineteenth century nationalism and liberalism on the use of race/caste terms and elite perceptions of identity.

\section{THE DEFINITION OF RACE/CASTE IN FRONTIER SONORA}

Until the late eighteenth century Sonora was a sparsely settled frontier region with an active mission program and a small settler population attracted by a series of boom and bust mining

(8) Jackson and Maddox, [5]. 
cycles or profits to be gained from farming and ranching for local markets. Jesuit missionaries opened the Sonora mission frontier in the first decades of the seventeenth century, and by the end of the century the black robes had organized mission communities as far north as the Santa Cruz Valley in modern southern Arizona. Miners and ranchers followed the establishment of the missions, and mining camps sprang up throughout the jurisdiction attracting a small but highly mobile group of miners who migrated from strike to strike. Settlers established ranches and farming hamlets, but frequently experienced difficulties because of raids by hostile Indians such as Apache. In 1768, Franciscan missionaries replaced Jesuits who had been expelled by royal order, and staffed Sonora missions until the end of the eighteenth century and in some instances even into the second and third decades of the nineteenth century (9).

During the course of the eighteenth century the settler population of Sonora grew, and the pattern of the rise and fall of temporary mining camps gave way to more permanent communities based on ranching and farming. According to one estimate the settler population of Sinaloa-Sonora grew from around 15,000 in 1700 to some 70,000 a century later (10). The growing complexity of Sonora society was reflected in changing settlement patterns shown in detailed censuses prepared at the end of the

(9) On the early development of Sonora see John Francis Bannon, S. J., The Mission Frontier in Sonora. 1620-1687. New York, 1955; John Augustine DonaHUE, S. J.; After Kino Jesuit missions in Northwesterm New Spain 1711-1767, St. Louis, 1969; James HASTINGS, ${ }^{2}$ People of Reason and Others: The colonization fo Sonora to 1767", Arizona and the West. Vol. 3, no. 4, 1961, pp. 321-340; Evelyn Hu-DEHART, Missionaries, Miners, and Indians: Spanish Contact with the Yaqui Nation of Northwestern New Spain 1533-1820, Tucson, 1981; Daniel REFF, Disease, Depopulation, and Culture Change in North western New Spain, 1518-1764. Salt Lake City, 1991; Juhn KeSSELl, Mission of Sorrows: Jesuit Guevavi and the Pimas, 16911767. Tucson, 1970; Robert H. JACKSON, «The Last Jesuit Censuses of the Pimeria Alta Missions, 1761 and 1766", The Kiva vol. 46 no. 4, 1981, pp. 243-272; Robert H. JACKSON, "Causes of Indian Population Decline in the Pimeria Alta Missions of Northern Sonora", Journal of Arizona History vol 24, no. 4, 1983, pp. 405-429; Robert H. JACKSON and Peter STERN, "Vagabundaje and Settlement Patterns In Colonial Northern Sonora", The Americas vol. 44, no. 4, 1988, pp. 461-481. Cynthia RADDING, "Las estructuras socio-economicas de las misiones de la Pimeria Alta 1768-1850", Noroeste de Mexico no. 3, 1979, pp. 1-124; Cynthia RadDING, "La acumulacion originaria de capital agrario en Sonora", Noroeste de Mexico, no. 5, 1981, pp. 15-46; Kieran McCARTY, O.F.M., A Spanish Frontier in the Enlightened Age: Franciscan Beginnings in Sonora and Arizona, 1767-1770, Washington, D.C., 1981; John KESSELL, Friars, Soldiers and Reformers Hispanic Arizona and the Sonora Mission Frontier 1767-1856 Tucson, 1976; Daniel MATSON and Bernard FONTANA, translators and editors, Friar Bringas Reports to the King: Methods of Indoctrination on the Frontier of New Spain 1796-1797 Tucson, 1977.

(10) Peter Gerhard, The North Frontier of New Spain, Princeton, 1982, p. 24. 
eighteenth century. In 1800, for example, the jurisdiction of Movas located in southeastern Sonora consisted of two mission communities inhabited by the remnant of the indigenous population as well as settlers who were moving into the mission communities, 10 ranches, and one mining camp (11).

Priests and colonial bureaucrats introduced the sistema de castas to northern New Spain, but the use of race/caste terms was not as rigidly or consistently followed as in central Mexico. Moreover, there was considerable variation in the use of race/caste terms across the northern frontier as well as in Sonora. Three case studies of the race/caste composition of frontier populations using censuses and parish registers demonstrate the variation in the use of terms. For the purposes of this discussion I will focus on the term "mestizo" where appropriate.

The first example is a study that documents the use of race/caste terms in a 1790 census of New Mexico with figures compiled for each jurisdiction by different officials. "Mestizos" reportedly constituted 29 percent of the population of the El Paso area, 38 percent of Albuquerque, 26 percent of Santa Fe, Tesuque, and Pecos, and 26 percent of Santa Cruz, San Juan, and Picuris (12).

Baptismal registers from two Chihuahua parishes, Tapacolmes 1757-1810 and Valle de San Buenaventura 1703-1799, shows a frequency of baptisms of children categorized as «mestizo" of 20 and 21 percent respectively. However, there was considerable variation in the frequency distribution of other race/caste terms: for example, baptisms of children categorized as "Espanoles» made up 13 and 40 percent respectively of the total. Moreover, priests stationed in the two parishes used a wide variety of terms including «mulato", "coyote», «indio», «lobo", «negro", and "castizo" (13).

Finally, Alta California, first colonized in 1769, provides an example of an embryonic frontier society where social stratification existed but race/caste terms were not commonly used. One

(11) Juan Manuel de Villa y Sanchez, Movas, February 3, 1800, «Padron General ... [del] Pueblo de la Purissima Concepcion de Movas... y sus Anexos", Documents in this archive are organized chronologically.

(12) Alicia TJARKS, "Demographic, ethnic and Occupational Structure of New Mexico, 1790", The Americas vol. 35, no. 1, 1978, pp. 45-88. For a further discussion of the caste system in New Mexico Adrian BustamanTE, "The Matter was Never Resolved: The Casta System in Colonial New Mexico, 1693-1823", New Mexico Historical Review no. 66, 1991, pp. 143-164.

(13) William GRIFFEN, Indican Assimilation in the Franciscan Area of Nueva Vizcaya Tucson, 1979, pp. 69, 87. 
of the few eighteenth century documents from Alta California that records race/caste terms was a census prepared in 1797 of a group of settlers recruited in the Guadalajara region to establish a planned community called the Villa de Branciforte. Spanishborn civil officials categorized the colonists as of mixed ancestry, but when the colonists stepped off the boat in Monterey most identified themselves as "spaniards". The colonists arrived in a community where they were not known, and claimed higher status calidad (14). Most other documents that mentioned the small settler population in Alta California used the generic term "gente de razon", which distinguished between the local indigenous population and colonists (15).

Some missionaries and parish priests in the seventeenth and early eighteenth centuries used race/caste terms in some Sonora mission/parish sacramental registers, but not all. One of the oldest surviving Sonora baptismal registers is for Los Santos Reyes de Cucurpe from the 1680s to the early years of the following century. One register contained the record or baptism of Indian children, but a second registered baptisms of the children of Yaqui from southern Sonora and workers on local ranches identified simply as «servants". The Jesuits stationed at Cucurpe did not use race/caste terms (16). Priests assigned to other parishes and missions in Sonora recorded race/caste terms in sacramental registers. For example, priests stationed at Nacosari which also included the Real de Basochuca made extensive use of race/caste terms in the early eighteenth century, but they also were describing populations that were essentially different from mission populations. A fragment of a baptismal register that covers the years 1705 to 1737 includes five caste terms including "espanol», "mestizo", «mulato», "coyote», and «nijora»,

(14) Robert JaCKSON, Edna KIMBro, Randy MillikeN, and Maryellen Ryan, "Como la sombra huye la hora: Restoration Research, Santa Cruz Mission Adobe, Santa Cruz Mission State Historic Park", unpublished manuscript on file with the State of California Department of Parks and Recreation, Sacramento, California.

(15) See, for example, a series of 1816 reports on the California missions found in AGEMS. In the report of San Jose mission, the Franciscan missionaries use the term "De Razon", a shortened form of "gente de razón": Fray Narciso Durán, and Fray Buenaventura Fortuny, February 16, 1816, "Catálogo de la Mis[io]n del Fr. San Jose", AGEMS. The missionaries stationed at neighboring Santa Clara mission used the complete term "gente de razon", Fray Magin Catalá, and Fray Jose Viader, February 25, 1816, "Ynforme, o estado de la M[isio]n de S[an]ta Clara en la Alta California", AGEMS.

(16) Los Santos Reyes de Cucurpe, Baptismal Registers, Magdalena Parish Archive, Magdalena, Sonora. 
as well as four ethnic terms such as «opata», «apache», and «jumano» (17).

The growth of the settler population, the increase of royal power as a consequence of the Bourbon reforms which placed more royal officials in Sonora, and the government demand for information on its New World possessions led to a strengthening of the colonial caste system. However, as it evolved in Sonora, the caste system evidenced considerable variability as priests categorized the population in an inconsistent fashion. Censuses prepared in the seventeenth and early to mid eighteenth centuries generally referred to the settler population using a generic term "gente de razon" ("people of reason"), that distinguished the settlers from the local indigenous population known as "gente sin razon" since they were legally defined as minors and wards of the Spanish crown. At the end of the eighteenth century ard in the first two decades of the following century censuses recorded more specific information on the race/caste identity of the Sonora population. However, there is clear evidence of fluidity and inconsistency in the use of race/caste terms to categorize people.

Table 1 summarizes the race/caste terms used by different priests to categorize the population of the parishes/missions they served in detailed censuses prepared in 1796, 1801, and 1814 . Priests used different race/caste terms, and in one instance made a distinction between "spaniards" born in Europe and America. In 1801, Franciscan missionary Joaquin Goita described the nonindigenous population of Cocospera located in the Pimeria Alta in northern Sonora as "mulatos». Franciscans at neighboring Pimeria Alta missions used other terms in 1801 censuses to describe the non-indigenous population: Josef Perez at San Ignacio used "european", "spaniards", "mestizo», "mulato;" while Bartolome Soeze at Saric used one term, «spaniards". Five years previously, in 1796, Francisco Yturralde used the terms "spaniard" and "coyote" for the non-indigenous population of Tubutama and Santa Teresa.

In addition to the variation between communities, terms used to describe the population of a single village changed over time depending on who the resident priest was. Or else a priest stationed at a single mission for a prolonged period of time changed the terms used to describe the same population. For example, in 1796 Franciscan Juan de Santisteban used the term "gente de razon" to describe the non-indigenous population of Cocospera.

(17) Nacosari Baptismal Register, Arispe Parish Archive, Arispe, Sonora. 
Five years later a new priest named Joaquin Goita used the term "mulato" to describe the same population. Thirteen years later Goita was at another Sonora mission calied Opodepe, and categorized the non-indigenous population as «spaniard" and "pardo". In 1796 and 1814 Salvador del Castillo censused the population of Cumuripa. In the first census he used the terms "spaniard" and "coyote", and in the second census the terms "spaniard" and "pardo" (see Table 1).

TABLE 1: USE OF RACE/CASTE TERMS IN SELECTED SONORA PARISH POLLS, 1796-1814

\begin{tabular}{|c|c|c|c|}
\hline Year & Priest & Parish & Terms Used \\
\hline \multirow[t]{8}{*}{1796} & Juan de Santisteban & Cocospera & Gente de Razon \\
\hline & Francisco Yturralde & Tubutama & Español, Coyote \\
\hline & Diego Pozo & San Jose de Pimas & Español, Coyote, Mulato \\
\hline & Domingo Moreno & Yecora & Español \\
\hline & Francisco Tamajon & Aribechi & $\begin{array}{l}\text { Español, Coyote, Moreno, } \\
\text { Mulato }\end{array}$ \\
\hline & Salvador del Castillo & Cumuripa & Español, Coyote \\
\hline & Ignacio Davalos & Tecoripa & Español, Mulato, Mestizo \\
\hline & Manuel Legarra & Cucurpe & Español, Mulato, Mestizo \\
\hline \multirow[t]{3}{*}{1801} & Joaquin Goita & Cocospera & Mulato \\
\hline & Josef Perez & San Ign. & $\begin{array}{l}\text { Europeo, Español, Mestizo, } \\
\text { Mulato }\end{array}$ \\
\hline & Bartolome Soeze & Saric & Español \\
\hline \multirow[t]{5}{*}{1814} & Joaquin Goita & Opodepe & Español, Pardo \\
\hline & Martin Perez & Ures & $\begin{array}{l}\text { Español Europeo, Español } \\
\text { Americano }\end{array}$ \\
\hline & Luis Romero & Bacerac & $\begin{array}{l}\text { Español, Negro, Mulato, Mes- } \\
\text { tizo }\end{array}$ \\
\hline & Salvador del Castillo & Cumuripa & Español, Pardo \\
\hline & Pedro Martinez & Matape & Español, Metizo, Pardo \\
\hline
\end{tabular}

Source: Robert H. Jackson, Demographic Collapse in the Mission Communities of Northwetern New Spain, forthcoming University of New Mexico Press; Ms. Francisco Yturralde, O.F.M., "Padron de esta Miss[io]n de S. Pedro y S. Pablo de Tubutama, y su visita Sta. Theresa hecho el dia 29 de Octubre de 1796”, BLB.

Not only did the terms used vary from mission to mission and priest to priest, but subjective decisions made by missionaries determined the category and status of new-born children. The subjectivity of these decision can be seen in cases of children sired by parents assigned different race/caste status, including marriages between Indians and non-Indians. As a general rule 
Sonora missionaries assigned a new-born child the category of the father, but there were exceptions. The eight censuses of the Pimeria Alta missions prepared in 1801 (18) contain eleven examples of mixed unions that had produced children. In seven cases the children were assigned the category of the father, in three cases the children were given the category of the mother, and in one instance the Franciscan preparing the census did not record the category of the child.

Several of the mixed unions recorded in the 1801 censuses pose interesting questions regarding the differences between $c a$ lidad and culture. Juan Nuñez, a resident of Tumacacori categorized as a "gente de razon" was married to a Yuma woman (the Yuma or Quechan were an Indian group living at the confluence of the Gila and Colorado Rivers) named Ygnacia Pena. Their young son Felix Nunez was listed as a "gente de razon", following the status of the father. In this instance the child of this union was biologically mixed, but how much Yuma culture did the boy absorb from his mother? A case from Cocospera makes the contradictions in the caste system even more evident. An Opata (an Indian group from central Sonora) named Francisco Pena was married to a woman Ygnacia Pena classified as a "mulato". Their children, who were biologically mixed, were listed in the census as Opata. A similar case appears in the Tubutama census. An Opata named Jose Garcia was married to a woman identified as a "gente de razon". Their child was listed as an Opata. In these two cases how much Opata culture did the children retain, and what beliefs and practices did the mothers bring to the families.

Finally, the San Ignacio census contains three contradictory cases. Bernardo Buriano (pima) and Juana Martinez (mulato) sired children classified as being Pima despite being biologically of mixed ancestry. The children of Juan Castro (mulato) and Maria Cabrera (pima) were listed as "mulatos". In these two

(18) Preserved in AGEMS: Fray Francisco Gutierrez, December 9. 1801, «Padrón de la Misión ... de San Joseph de Tumacacori, Año de 1801; Fray Joaquín Goita, December 1801, «Padrón de las familias de los hijos del Pueblo de Cocospera». Fray Josef Pérez, December 31, 1801, «Padrón de los naturales y vecinos ... de la misión de San Ignacio en la Pimerias Altam. Fray Bartolomé Soices, Saric, December 14, 1801, "Padrón de los Yndios y vecinos de esta mision de Nra. Sra. de los Dolores del Saric", Fray Francisco Yturralde, December 26, 1801, "Padrón de los Yndios del Pueblo de San Pedro y San Pablo de Tubutama», Fray Francisco Moyano, January 3, 1802, "Padron de las familias de Yndios y vecinos de San Francisco del Ati» Fray Juan Bautista Llorens, December 12, 1801, «Padron del Pueblo y Misión de San Francisco Xavier del Bac» Fray Andres Sánchez, December 21, 1801, "Padrón de las familias y número de almas de este pueblo de la Purísima Concepción de Caborca». 
cases the children were assigned the status of the father, yet in the same census the children of a mixed family were assigned the status of the mother. The children of Joseph Cordova (Opata) and Maria Arment (mulato) appeared in the census as "mulatos".

Priests also assigned race/caste identity in sacramental registers, registers of baptisms and marriages records (diligencias matrimoniales) which consisted of the documentation of the formal investigation into the proposed marriage of couples. In the baptismal registers priests assigned a race/caste status to a newborn child, and the idiosyncrasies of each individual priest had a bearing on the choice of the category assigned. In the case of the diligencias matrimoniales the idiosyncrasies of the priests also appear to have played a role in the choice of the category assigned to a couple, which contradicts the conventional wisdom that prospective bride and groom influenced the choice of calidad. Few sacramental registers survive from Sonora missions in the seventeenth century, and the most complete records are from the late eighteenth and early nineteenth centuries.

In the last decades of the eighteenth century most but not all missionaries and priests stationed in Sonora recorded the race/caste status of new-born children. Fray Joseph Medina, for example, stationed at Ures in the late 1770 s, provided a specific race/caste identity only to Indians. On December 26, 1778, Medina baptized a new-born girl who he simply identified as "de este Pueblo [Ures]». A week later, on January 2, 1779, Medina baptized another new-born girl he identified as both a "Hiaqui" and "una india de aqui de este Pueblo». Four days later, on January 6, 1779, Medina baptized a third new-born girl he identified as "una india de Santa Rosalian (19). In contrast, the missionaries stationed a Sahuaripa in the same years consistently assigned race/caste terms to new-born children (20).

An analysis of the categorization of new-born children by the priests assigned to one Sonora parish, Sahuaripa between 1781 and 1824, provides important insights to the creation of identity in colonial Sonora. Sahuaripa, located on the Rio Sahuaripa which is a tributary of the Rio Yaqui located in southeastern Sonora, was originally inhabited by Opata, one of four major ethnic groups in Sonora. Jesuits established a presence at Sahua-

(19) Ures Baptismal Registers, Ures Parish Archive, Ures, Sonora.

(20) Sahuaripa Baptismal Register, Sahuaripa Parish Archive, Sahuaripa, Sonora. 
ripa and other communities in the Sahuaripa Valley in the late 1620 s (21).

TABLE 2: FREQUENCY (IN PERCENTAGES*) OF THE USE OF SIX RACE/CASTE TERMS IN THE SAHUARIPA MISSION BAPTISMAL REGISTER, $1781-1824^{\circ}$

\begin{tabular}{ccccccc}
\hline Years & Indio & Español & Mestizo & Mulato & Lobo & Coyote \\
\hline $1781-1802$ & 14 & 29 & 11 & 22 & 9 & 9 \\
$1803-1806$ & 10 & 23 & 3 & 5 & 0 & 9 \\
$1807-1813$ & 13 & 38 & 0 & 2 & 1 & 35 \\
$1814-1824$ & 14 & 19 & 34 & 12 & 1 & 15 \\
\hline
\end{tabular}

- Percentages have been rounded off.

- Other categories listed in the baptismal register included Opata, Yaqui, Morisco, Tresalbo, Moreno, Negro, and Pardo. In addition, 89 records of baptisms did not include a race/caste category. The total number of baptisms was: $1781-1802=433 ; 1803-1806=258 ; 1807-1813=356 ; 1814-1824=882$.

Source: San Miguel de Sahuaripa Baptismal Registers, Sahauripa Parish Archive, Sahuaripa, Sonora.

The Franciscans who replaced the exiled Jesuits described Sahuaripa in a 1773 report. The community, located in a narrow valley, supported itself through agriculture, although the Franciscans stressed that flash floods and variable rainfall periodically damaged the crops generally grown in the river bottom. Crops grown included Old and New World cultigens: corn, beans, chickpeas, peas, sugar cane, and fruit. The Franciscans reported little livestock at Sahuaripa, although Jesuit inventories of the mission in the 1750s and 1760s reported 100-200 head of cattle, 300-600 horses, 50-200 mules, and 700-2,2200 sheep and goats. Apache raids may have depleted the mission herds (22). The farming and ranching provided for the basic subsistence needs of the Indians living at the mission, but surpluses may have been sold to the growing settler population in the valley.

Two related demographic trends occurred at Sahuaripa and surrounding communities in the Sahuaripa Valley. The first was

(21) George Eckhart, "A Guide to the History of the Missions of Sonora, 1614-1826", Arizona and the West vol. 2, no. 2, 1960, pp. 165-183.

(22) Charles Carlisle and Bernand FonTANA, translators and editors, «Sonora in 1773: Reports by Five Jaliscan Friars", Arizona and the West vol. 11, no. 1, 1969, pp. 39-56; Maria ARBElaEz, "The Sonoran Missions and Indian Raids of the Eighteenth Century", Journal of the Southwest, vol. 33, no. 3 1991, 366-386. 
the decline in the Opata population. Anthropologist Daniel Reff estimated a contact population in the Sahuaripa Valley of some 8,750 , and a decline in the numbers to some 461 in the mid 1760 s (23). The second was the establishment of mining camps and other settlements in the Sahuaripa Valley and surrounding valleys. The first mining strike was at Tacupeto in 1675, and over the next century there were other short-lived mining booms. The settler population of Ostimuri, the administrative jurisdiction that included the Sahuaripa Valley, grew from 3,641 in 1760 to some 6,500 in 1804, and the Sahuaripa Valley was one of the most densely settled areas in the province (24). In 1799, the settler population in the valley was 1,115 , the numbers grew to 1,255 in 1802 , and 1,401 in 1806 (25). Many settlers went to live in Sahuaripa and the other mission communities, where the remaining Indians were increasingly marginalized and in some instances lost control over the lands previously assigned to the missions (26).

TABLE 3: RACIAL ENDOGEMY AND EXOGEMY IN SAHUARIPA PARISH 1810-1823, IN PERCENTAGES

\begin{tabular}{ccccc}
\hline Years & $\begin{array}{c}\text { Marriage Within } \\
\text { Race/Caste Group }\end{array}$ & $\begin{array}{c}\text { Marriage Outside } \\
\text { Race/Caste Group }\end{array}$ & $\begin{array}{c}\text { Information } \\
\text { Not Given }\end{array}$ & $\begin{array}{c}\text { Sample } \\
\text { Size }\end{array}$ \\
\hline $1810-1813$ & 91 & 0 & 9 & 21 \\
$1814-1823$ & 75 & 22 & 3 & 67 \\
\hline
\end{tabular}

Source: Sahuaripa Parish Diligencias Matrimoniales, Sahuaripa Parish Archive, Sahuaripa, Sonora.

Surviving baptismal records for Sahuaripa cover only the years 1781 to 1856 . However, in 1824, following the declaration of the first federal republic in Mexico, the practice of recording race/caste terms in sacramental registers was dropped. Therefore, the analysis of patterns of assigning race/caste identity to new-

(23) Reff, Disease, [9] p. 222.

(24) Gerhard, [10], p. 269.

(25) "Noticia de las Misiones que ocupan los Religiosos ... pertenecientes a la Provincia de Jalisco", AF. 36/806; "Noticia de las Misiones que ocupan los Religiosos ... de la Provincia de Jalisco", AF 36/815; "Noticia de las Misiones que ocupan los Religiosos ... pertenecientes a la Santa Provincia de Xaliscon, AF 37/829.

(26) Radding describes a similar process in other parts of Sonora. See her article "Acumulacion originaria de capital agrario" en [9]. 
born children is limited to the years 1781-1824. During these years four priests were stationed at Sahuaripa: Pedro de la Cueva (1781-1803); Ramon Mendieta (1803-1807); Jose Cuevas (18071813); and Dionisio Onederra (1814-1824). Each of the four priests showed a marked preference for specific race/caste terms used to categorized new-born children. All four priests fairly consistently identified Indian children: the percentage frequency of new-borns identified as «indio" ranged from 10 to 14 percent. The greatest variation occurred in the casta categories. The percentage frequency of the category "spaniard" fluctuated from 19 to 38 percent. It was from 0 to 34 percent for the "mestizo" category, from two to 22 percent for the «mulato" category, and from nine to 35 percent for the "coyote" category (see Table 2). Pedro de la Cueva showed a preference for the "mulato" category, Jose Cuevas identified more children as "coyotes", and Dionisio Onederra categorized children as "mestizo" and "coyote" while at the same time making less use of the "spanish" category then had his predecessor Cuevas.

Interpretation of marriage records is somewhat more difficult because the couples getting married had influence over the decision made over the placement in a race/caste category. However, an interesting pattern emerges in the extant set of diligencias matrimoniales which cover the years 1810 to 1823 and the terms of two priests, Jose Cuevas and Dionisio Onederra. The diligencias matrimoniales contained different categories of information to identify the prospective grooms and brides, including age, place of residence, and name of parents. In most of the investigations the first item recorded was calidad (27). Both Cuevas and Onederra applied the same race/caste category to both the groom and bride in the majority of the cases, although as shown in Table 3 Cuevas followed this practice more consistently. Moreover, Cuevas, who identified 38 percent of the children he baptized as "spaniard", used the same term to categorize the majority of the couples who came before him to get married. Onederra, on the other hand, used a larger number of race/caste terms, and also recorded a larger percentage of marriages between different categories.

Censuses and parish registers from Sonora show clear subjectivity by individual priests in recording the race/caste identity of new-born children. The evidence for the use of race/caste terms in marriage records is ambiguous, but suggestive of the need for

(27) Diligencias Matrimoniales, Sahuaripa Parish Archive, Sahuaripa, Sonora. 
further research. The use of terms, however, indicates some fluidity in the caste system as it evolved in Sonora. The second case study illustrates a different aspect of the creation of identity in colonial Spanish America; the relationship between the decline in the population of kindios", changes in the tribute system, and shifts in elite perceptions as to what an kindio" and "mestizo" were in the Cochabamba region of Bolivia.

\section{INDIO vs METIZO: RACE/CASTE IN COCHABAMBA, BOLIVIA}

Cochabamba was known even in the late colonial period as a region populated by mestizos, although the extensive mestizaje that a number of scholars argue occurred in the region was as much a sleight of hand (28). In other words, censuses and parish registers recorded declines in the population of "indios" and the growth in the number of mixed-blood "mestizos" and "cholos". However, mestizaje more accurately reflected racial/caste drift, especially in the stereotypical behaviors that members of the local elite used to distinguish between "indios" and "mestizos", and the form of access to land which elites also used to divide the peasantry into different segments. Changes in the rural society of Cochabamba in the nineteenth century contributed to the erosion of the race/caste system, and the breakdown in the colonial order in rural Cochabamba resulted in the decline and in some instances the near complete disappearance of peasants classified as «indios». Late nineteenth century liberal policies played an important role in initiating economic and social change.

For the purposes of the analysis here I focus on one subregion in Cochabamba, the valley know as the Valle Alto or Valle de Cliza. The Valle Alto was the largest of the valleys (former lake beds) in the Cochabamba region that were the centers of population and agriculture. Prior to the Spanish conquest of Cochabamba beginning in 1539 the Valle Alto was a sparsely settled mosaic of ethnic communities that generally lived around the base of the mountains that surround the valley. A marshy area occupied a large section in the center of the valley (29). Although indigenous corporate communities in other areas laid claim to lands, there were no communities in the Valle Alto. In the two

(28) Jackkson and Maddox, [5].

(29) Raimund Schramm, "Mosaicos etnohistoricos del Valle de Cliza (Valle Alto Cochabambino), Siglo XVI», Historia y Cultura no. 18, 1991, pp. 3-41. 
centuries following the conquest Spaniards carved haciendas out of largely vacant land. At the end of the seventeenth century there were 24 haciendas in the valley, and 146 in 1831 shortly following Bolivian independence (30).

Hacienda labor came primarily from migrants from the altiplano (high altitude plateau), especially districts subject to the mita labor draft to Potosi and other mining centers. The classification of hacienda labor changed during the course of the colonial period. At the end of the seventeenth century yanaconas («indios" absent from their native community or with no community affiliation legally bound to the land) were common on haciendas in the Valle Alto. However, yanaconas were extremely mobile. A 1692 census of yanaconas showed that 62 percent of males aged 18 to 50 were absent from their hacienda of residence (31). By the early nineteenth century colonaje (service tenantry) was the dominant form of hacienda labor, and yanaconas were found primarily on church-owned estates: in 1805, 1,393 yanaconas still lived in the Valle Alto, most on large haciendas owned by convents and monasteries (32). Both yanaconas and colonos received a subsistence plot from the hacienda owner and provided labor for crops grown on the hacienda demesne. The major difference was the legal status of yanaconas. In the 1880s, 12,890 colonos lived and worked in the Valle Alto (33).

The shift from "indio" to "mestizo" in -the Valle Alto resulted from several factors. One was the erosion of the tribute system (adult males 18 to 50 paid tribute), especially in the nineteenth century. Tributary was analogous to «indio». The Spanish government created two separate tribute categories which defined uindio" peasants on the basis of the form of access to land. Originarios generally were members of corporate indigenous communities with full rights to community lands. Forasteros were tributaries absent from their native community who paid a sma-

(30) Jose Gordillo Claure, «El proceso de extinción del yanaconaje en el valle de Cochabamba. (Análisis de un padrón de yanaconas 1692)" unpublished manuscript; Padrones de Tributarios, Cliza Province 1831. (hereinafter cited as PT, ANB).

(31) Idem.

(32) Robert H. JACKSON, «Evolucion y persistencia del colonaje en las haciendas de Cochabamba", Siglo XIX, vol. 3, no. 6 1988, pp. 145-162; Brooke LaRSON, Colonialism and Agrarian Transformation In Bolivia: Cochabamba 1550-1900, Princeton, 1988, p. 197. A more detailed discussion of yanaconas in the Valle Alto in 1805 appears in Larson's PhD dissertation, "Economic Decline and Social Change in an Agrarian Hinterland: Cochabamba (Bolivia) in the Late Colonial Period", PhD dissertation, Columbia University, 1978.

(33) Jackson, [32]. 
ller amount of tribute to the government. These categories marked legal-fiscal status which artificially divided the rural population into categories that did not reflect socio-cultural realities, but which have been given considerable meaning by many scholars who believe the artificial distinctions were meaningful beyond government fiscal policy. Moreover, the categories were manipulated by the Crown and later the Bolivian government. For example, in the early 1860s the Bolivian government changed the status of forasteros living in Quirquiavi (a highland district in Cochabamba) to that of originarios, and created a new corporate indigenous community. In other cases the government increased the number of originarios in existing communities in order to collect higher tribute from the newly created originarios. This occurred in Capinota in the late 1850s (34).

During the nineteenth century the number of tributaries declined in Cochabamba despite efforts by the government to bolster the number of originarios. Between 1838 and 1877, the total number of tributaries throughout Cochabamba department dropped from 11,163 to 6,900. The greatest decline occurred on haciendas, where the number of hacienda workers classified as tributaries dropped by 57 percent.

TABLE 4: DISTRIBUTION OF TRIBUTARIES IN COCHABAMBA DEPARTMENT BY TYPE OF SETTLEMENT

\begin{tabular}{|c|c|c|c|c|c|c|}
\hline \multirow{2}{*}{$\begin{array}{l}\text { Type of } \\
\text { Settlement }\end{array}$} & \multicolumn{2}{|c|}{$\begin{array}{r}1838 \\
\text { Index }\end{array}$} & \multicolumn{2}{|c|}{1858} & \multicolumn{2}{|c|}{1877} \\
\hline & Number & $\begin{array}{c}(1838= \\
100\end{array}$ & Number & Index & Number & Index \\
\hline Community & 6,783 & 100 & 5,380 & 79 & 4,985 & 74 \\
\hline Hacienda & 4,284 & 100 & 2,821 & 66 & 1,843 & 43 \\
\hline City/Town & 96 & 100 & 44 & 46 & 72 & 75 \\
\hline
\end{tabular}

Source: Erwin Grieshaber, «Survival of Indian Communities in Nineteenth Century Bolivian, PhD dissertation, University of North Carolina Chapel Hill, 1977, pp. 106107.

The decline in the population of tributaries can be directly linked to the drop in the number of peasants classified as «indios». Table 5 summarizes the size of the «indion population reported in [5].

(34) PT, ANB, Arque Province, various years. Also see JAXKson an MAdDox, 
the Valle Alto in selected years. The growth in the number of «indios" at the end of the eighteenth century reflects efforts by the colonial government to increase the number of originarios, as well as the source of information. Officials who prepared general censuses might use different subjective criteria to define who an «indio" was, whereas most nineteenth century figures for the population of "indios" comes from tribute records which recorded the number of tributaries as well as the total number of individuals that the officials responsible for preparing the tribute rolls classified as «indios" including the families of tributaries. Table 6 shows the decline in the number of tributaries and shift in the population of "indios" in selected jurisdictions in the Valle Alto. As the number of tributaries declined, so to did the "indio" population.

Hacienda owners colluded with tribute officials to remove their workers from the rolls of tributaries: hacienda owners either had to pay the tribute obligations of their service tenants classified as tributaries, or else allow them time off to work elsewhere to earn money to pay tribute. The influence of liberalism on elite perceptions with its stress on the integration of the "Indian" into society also played a role. As the government phased out the tribute system in the late nineteenth century, it was easier for service tenants on haciendas to escape tributary status.

A second factor was the profound change that occurred in the rural society of Cochabamba in the late nineteenth and early twentieth century. Liberal economic policy and the completion of railroads between the altiplano and coast led to the reorientation of Bolivia's economy, the gradual loss by Bolivian grain producers of traditional markets in the southern Andes, and the opening of Bolivia to imports of grain and flour that competed with grain and flour from Cochabamba, which led to a severe economic crisis in the 1890s. Haciendas experienced rapid fragmentation, especially in the 1890s and first decades of the present century, and thousands of service tenants acquired land and thus changed their status to that of small landowners known locally as piqueros who were generally categorized as "mestizos" or «cholos". 
TABLE 5: INDIAN POPULATION REPORTED FOR CLIZA PARTIDO/PROVINCE IN SELECTED YEARS

\begin{tabular}{lr}
\hline Year & Polulation \\
\hline 1683 & 3,581 \\
1737 & 7,478 \\
1786 & 16,227 \\
1792 & 16,355 \\
1797 & 17,553 \\
1803 & 17,345 \\
1838 & 7,554 \\
1846 & 7,344 \\
1850 & 6,675 \\
1852 & 8,242 \\
1855 & 7,747 \\
1858 & 5,953 \\
1871 & 4,607 \\
1877 & 3,999 \\
\hline
\end{tabular}

Source: Brooke Larson, Colonialism and Agrarian Transformation in Bolivia: Cochabamba, 1550-1900 (Princeton, 1988), p. 326; Erwin Grieshaber, See Table 4, pp. 106-107; Pablo Macera, Bolivia tierra y poblacion, 1825-1936 (Lima, 1978), p. 103.

TABLE 6: NUMBER OF TRIBUTARIES AND INDIAN POPULATION REPORTED FOR SELECTED JURISDICTIONS IN THE VALLE ALTO, COCHABAMBA

\begin{tabular}{rrrrrrrrr}
\hline & \multicolumn{4}{c}{ Punata } & \multicolumn{3}{c}{ San Benito } & \multicolumn{2}{c}{ Arani } & \multicolumn{2}{c}{ Paredon } \\
Year & Trib. & Pop. & Trib. & Pop. & Trib. & Pop. & Trib. & Pop. \\
\hline 1846 & 151 & 1,047 & 93 & 752 & 166 & 1,031 & 140 & 858 \\
1850 & 110 & 1,046 & 99 & 693 & 135 & 1,378 & 96 & 1,192 \\
1867 & 55 & 978 & 85 & 900 & 50 & 1,037 & 22 & 521 \\
1880 & 16 & 230 & 23 & 124 & 8 & 167 & - & - \\
\hline
\end{tabular}

Source: Padrones de Tributarios, ANB. 
TABLE 7: PERCENTAGE DISTRIBUTION OF BAPTISMS IN TARATA PARISH BY RACE/CASTE TERMS IN SELECTED YEARS

\begin{tabular}{cccccccr}
\hline Years & Indio & Mestizo & Español & Mulato & Esclavo & Not Given Baptisms \\
\hline $1698-1707$ & 67.7 & 19.1 & 7.0 & 0 & 0.2 & 4.2 & $\begin{array}{c}\text { Total } \\
1747-1755\end{array}$ \\
\hline 66.5 & 27.9 & 24.8 & 0.4 & 0.1 & 0 & 3,867 \\
$1800-1809$ & 24.7 & 54.6 & 20.0 & 0.2 & 0.4 & 0 & 8,749 \\
$1816-1825$ & 20.4 & 57.0 & 22.2 & 0 & 0.3 & 0 & 10,490 \\
$1870-1879$ & 0.2 & 80.0 & 19.9 & 0 & 0 & 0 & 8,668 \\
\hline
\end{tabular}

Source: Guido Guzman, Walter Sanchez, David Mercado, and Abel Bustamante, "Indios y proceso de mestizaje (Tarata)", unpublished manuscript.

The number of properties in the Valle Alto grew rapidly as the number of small parcels proliferated. In the early $1880 \mathrm{~s}$ there were 5,842 separate properties in the valley, and 16,963 around 1916. In three jurisdictions, Cliza, Toco, and Tolata, the number of properties grew from 1,253 in the 1880 s to 7,114 in 1924 (35). Many service tenants acquired land as the market in small parcels grew, or else migrated to work in Bolivian and Chilean mines or sugar estates in northern Argentina. Between 1882 and around 1916, the number of colonos in the Valle Alto dropped from 12,890 to 7,888 (36). However, the growth in the number of small properties in the valley began as early as the 1840 s as traditional markets began to shrink. Service tenants classified as uindios" may have obtained small parcels of land from fragmenting haciendas, and thus changed their status to piqueros generally considered to be «mestizos».

The shift in identity from «indio" to «mestizo" can also be documented in extant parish registers. I consider here data from two parishes: Tarata, an important market town in the Valle Alto, and Paredon, a mountainous district bordering the valley.

Samples of race/caste terms assigned to new-born children in Tarata parish shows a progressive decline in the categorization of children as "indios" and a shift to the use of the "mestizo" category. In the first sample period (1698-1707) 68 percent of new-born children were designated «indios». Within a century

(35) Honorio PINTo, Bolivia tierra y poblacion, 1844-1939. Lima, 1978; Gustavo RodrígUez OSTRIA and Humberto SOLARES, Sociedad obligarchica, chicha y cualtura popular. Cochabamba, 1990, p. 21; Robert H. JACKSON, "Cambios en la tenencia de la tierra en la provincia de Cliza (1860-1930) y origenes de los sindicatos campesinos bolivianos", Historia y Cultura, no. 18, 1991. pp. 99-110.

(36) JACKSON, [32]. 
(1800-1809) only a quarter of the children were identified as "indios", and the percentage frequency of "mestizo" and "spaniard" had increased significantly. By the 1870 s 80 percent of new-born children were categorized as "mestizo", and less than one percent «indio" (see Table 7).

TABLE 8: PERCENTAGE DISTRIBUTION OF BAPTISMS OF INDIOS BY CATEGORY IN TARATA PARISH

\begin{tabular}{ccccc}
\hline Years & $\begin{array}{c}\text { Indio } \\
\text { Libre }\end{array}$ & $\begin{array}{c}\text { Indio } \\
\text { Yanacona }\end{array}$ & Indio & $\begin{array}{c}\text { Total } \\
\text { Baptisms }\end{array}$ \\
\hline $1698-1707$ & 88.8 & 2.3 & 8.7 & 2,326 \\
$1747-1755$ & 55.9 & 2.8 & 41.1 & 1,704 \\
$1800-1809$ & 0 & 0.6 & 99.4 & 2,167 \\
\hline
\end{tabular}

Source: Same as Table 7.

TABLE 9: BAPTISMS AND BURIALS IN TARATA PARISH BY RACE/CASTE CATEGORY, 1800-1809

\begin{tabular}{lccc}
\hline Race/Caste Category & Baptisms & Burials & Balance $+/-$ \\
\hline Indio & 2,167 & 3,307 & $-1,140$ \\
Mestizo & 4,780 & 2,314 & $+2,466$ \\
Español & 1,748 & 838 & +910 \\
\hline
\end{tabular}

Source: Same as Table 7.

TABLE 10: PERCENTAGE DISTRIBUTION OF BAPTISMS IN PAREDON PARISH BY RACE/CASTE TERMS

Total

\begin{tabular}{ccccccc} 
Years & Indio & Mestizo & Español & Mulato & Not Given & Baptisms \\
\hline $1788-1797$ & 48.4 & 33.7 & 16.5 & 1.4 & 0 & 3,295 \\
$1813-1822$ & 28.1 & 54.9 & 16.2 & 0.7 & 0 & 1,821 \\
$1827-1836$ & 10.7 & 79.2 & 9.6 & 0 & 0 & 2,823 \\
$1837-1842$ & 0 & 89.5 & 10.4 & 0.1 & .03 & 2,655 \\
$1858-1863$ & .03 & 90.1 & 09.0 & 0 & .87 & 3,000 \\
\hline
\end{tabular}

Source: Paredon Parish Baptismal Registers, Archivo del Arzobispado de Cochabamba, Cochabamba, Bolivia. 
Terms used to identify «indios" also shifted. At the end of the seventeenth century 89 percent of the baptisms of new-born Indian children used the term "indio librew, to distinguish the socalled free «indios" from yanaconas. A century later (1800-1809) the term «indio libre" no longer appeared in the baptismal register, and had been replaced by «indion. As yanaconaje declined in importance the distinction between yanaconas and free «indios" was no longer important.

Was the decline in the "indio" category a consequence of demographic patterns, or shifting perceptions of identity? More detailed demographic studies are need of the population of Cochabamba, but evidence suggests that demographic patterns alone could not account for the rapid decline in the number of people classified as "indios». Table 9 summarizes a ten year sample of baptisms and burials from 1800 to 1809 broken down into three race/caste categories. The population of "mestizos" and "spaniards" grew, while that of Indians declined. Superficially it might appear that the Indian population was actually declining, but another factor must be considered. The number of children being categorized as «indios» was steadily dropping in the last years of the eighteenth century, whereas the priests at Tarata may have continued to categorize adults as «indios». The deficit may have resulted from fewer children being categorized as «indios», and normal mortality among the segment of the population still categorized as «indios" (see Table 9).

Evidence from Paredon parish seems to support this interpretation. The decline in the percentage frequency of new-born children categorized as uindios" occurred very rapidly. In a sample from the years 1788 to 1797,48 percent of new-born children were categorized as «indios". A second sample from the years 1813 to 1822 shows that only 28 percent of new-borns were classified as «indios». Finally, after 1836 priests stationed in Paredon virtually discontinued use of the «indion category. Over a period of roughly 50 years the percentage frequency of newborn children classified as «indios" dropped from nearly half to virtually none. Children previously categorized as «indios» were now listed as "mestizos». Over the same years the percentage frequency of new-borns categorized as «mestizos" increased from 34 percent to 90 percent, the result of a demographic sleight of hand (see Table 10). The decision to drop the use of the «indio» category may have been a political one. 


\section{CONCLUSIONS}

The two case studies examined here provide important insights to the process of the creation of identity in Spanish America, particularly the inconsistency and subjectivity of race identity that Harris pointed to in his 1964 book. The subjectivity of the race/caste information in censuses and parish registers renders analyses of colonial Spanish American society based upon these sources suspect unless other factors such as culture are taken into account. This caveat is especially true for studies that fail to document changed elite perceptions of race and society, and shifts in government social policies.

Some studies of social history based upon race/caste terms and the concept of a functioning caste system carry with them a number of the same assumptions that underlay Spanish colonial social policy: the assumptions that meaningful distinctions existed between individuals classified as "indios" or "mestizo", and that indigenous culture was static and Spanish culture in America did not incorporate elements of indigenous culture. They view society from the perspective of an inflexible and rigid Spanish American caste system as understood by the same officials who created and tried to enforce it. Gootenberg's study of Peruvian society in the 1820 s shortly following independence is typical of studies that contain elements of this view of society. Mestizo peasants who Gootenberg considers to be essentially different from indigenous peasants have to mimic ayni, which is an element of indigenous culture. Gootenberg's understanding of Peruvian rural society seems to rule out the possibility that indigenous culture changed and adopted elements of Spanish culture, especially material culture such as dress, food, use of horses and other European introduced livestock, and the language spoken. Gootenberg's mestizo peasants were more likely the indigenous peasants described in the mid-seventeenth century as making minor changes in dress and speech so as to conform to Spanish stereotypical notions of what Indians and mestizos were (37).

Use of Spanish concepts of race and caste are seductive for modern researchers, because they carry with them the authority of written documents and are easily quantified. This approach, however, tends to over simplify the complexities of colonial Spanish American society, and fails to deal effectively with elements

(37) Quoted in JACKSON and MADDOX, [5]. 
which are more difficult to identify such as elements of culture, social practices, etc. Concepts such as calidad certainly had significant meaning, but the Spanish caste system was an artifact of Spanish policy that had more to do with abstract Spanish perceptions and little to do with social and cultural realities.

\section{Appendix 1: Theoretical Meaning of Selected Race/Caste Terms in Mexico and Peru According to Magnus Morner}

Mexican Meaning

Spaniard + Indian = Mestizo

Mestizo + Spaniard $=$ Castizo

Mestizo + Spaniard $=$ Castizo

Castizo + Spaniard $=$ Spaniard

Spaniard + Negro = Mulato

Spaniard + Mulato $=$ Morisco

Morisco + Spaniard $=$ Albino

Spaniard + Albino $=$ Torna Atras

Indian + Torna Atras $=$ Lobo

Lobo + Indian $=$ Zambaigo

Zambaigo + Indian = Cambujo

Cambujo + Mulato = Albarazado

Albarazado + Mulato = Barcino

Barcino + Mulato $=$ Coyote

Coyote + Indian $=$ Chamiso

Chamiso + Mestizo $=$ Coyote Mestizo

Coyote Mestizo + Mulato $=$ Ahi $\mathrm{Te}$

Estas

\section{Peruvian Meaning}

Magnus Morner, Race Mixture In the History of Latin America (Boston, 1967). 